\title{
Evaluation of the Protective Effect of Hibiscus sabdariffa L. Calyx (Malvaceae) Extract on Arsenic Induced Genotoxicity in Mice and Analysis of its Antioxidant Properties
}

\author{
Ilika Ghosh, Sonia Poddar and Anita Mukherjee*
}

Cell Biology and Genetic Toxicology Laboratory, Department of Botany, University of Calcutta.35, Ballygunge Circular Road, Kolkata 700019, India

\begin{abstract}
The present study envisages the antigenotoxic property of Hibiscus sabdariffa L. (Roselle) calyx extracts that is presumably attributed to its antioxidant properties. The dried calyx extracts of Roselle were administered to male albino mice at doses of 50,100 , and $150 \mathrm{mg} / \mathrm{kg}$ body weight for 7 days followed by a single dose of interperitoneal (i.p.) injection of sodium arsenite $(2.5 \mathrm{mg} / \mathrm{kg}$ body weight) and the extent of DNA damage was analysed by widely used Comet assay. The results revealed that the calyx extract of Roselle inhibited the DNA damage induced by sodium arsenite in a dose dependent manner. The presence of phytochemical constituents such as polyphenols and flavonoids were ascribed to the observed changes. The antioxidant efficacy was substantiated by applying Ferric Reducing Antioxidant Power (FRAP) and 2, 2-di(4-tert-octylphenyl)-1-picrylhydrazyl (DPPH) assays.
\end{abstract}

\section{Keywords}

Hibiscus sabdariffa; Malvaceae; Antioxidant; Antigenotoxic; Comet assay

\section{Introduction}

Advancement in medicinal plant research has undergone a stellar growth during the last decade. The exponential growth in the popularity of natural plant remedies has stirred up an enormous surge in need for information regarding the properties and uses of medicinal plants. Based on fact that plants like Hibiscus sabdariffa L. (Malvaceae) is used both in food and beverage was given special attention as regards medicinal plant research is concerned [1,2]. H. sabdariffa is commonly known as Roselle or Red Sorrel in English and in Arabic as Karkadeh. It is widely cultivated in Central and West Africa and in South-East Asia. In the Indian states of West Bengal, Bihar and Orissa, H. sabdariffa (var sabdariffa) is grown for its edible calyx and H. sabdariffa (var altisima) is cultivated as an alternative to jute in regions where jute plants cannot be grown. The fruits bear persistent, stout, bright red, fleshy calyx that are used for preparing jam, jellies, and syrups. The dried calyx extracts are consumed as hot and cold beverages around the world. Roselle calyx and leaves have been reported to have many therapeutic effects and are traditionally used in countries like Taiwan, Philippines, Myanmar and Africa for medicinal purposes as well as a functional food in China. In folk medicine, the calyx extracts are used for the treatment of several ailments, including high blood pressure, liver illnesses and fever [3-5].

H. sabdariffa leaves are reported to have antiscorbutic, emollient, diuretic, refrigerant and sedative properties. The plant is also known to have antiseptic, aphrodisiac, astringent, antioxidant, cholagogue, demulcent, digestive, purgative, resolvent, and anti tumor properties [6]. H. sabdariffa is used as a folk remedy in the treatment of abscesses, bilious conditions, cancer, cough, debility, dyspepsia, fever, hangover, heart ailments, hypertension, hepatoprotection, and neurosis [7-10].

The administration of antioxidant natural products to treat or prevent environmentally induced toxicity is a promising field of research. A wide variety of herbs, fruits and vegetables have been found to be protective against a wide range of ailments and this effect has been ascribed partly to the antioxidants contained therein, in particular, the phenolic compounds [11]. The aqueous $H$. sabdariffa calyx extracts aqueous extracts (HSE) besides cathartic activity [12] was found to possess profound antimutagenic [13], antitumour [14], antigenotoxic and antioxidant actions [15]. The role of natural antioxidants and to determine their potential always remained a question of great interest which lead to develop various in vivo and in vitro techniques [16].

Arsenic 'As' is a known human carcinogen and teratogen. It is ubiquitously present in the Environment where it occurs as $\mathrm{As}^{3+}$ and $\mathrm{As}^{5+}[16,17]$ Contamination of drinking water with As is a serious environmental problem worldwide. It is alarming that in Bengal region (Asia) and elsewhere its level reached $3.7 \mathrm{mg} / \mathrm{L}$, which is far above the World Health Organization (WHO) and United States Environmental Protection Agency (USEPA) permissible limit [18-20]. Arsenic compounds were used in the present study to understand the protective nature of $H$. sabdariffa. In earlier studies several crude extracts of plants and vegetables were shown to significantly reduce the cytotoxic and carcinogens effects of toxic metals and chemical such as: zinc, lead, sodium arsenite, mitomycin $\mathrm{C}$ and cyclophosphamide in bone marrow cells [21-23]. The present study elucidates the antigenotoxic potential of HSE in a dose dependent manner which can presumably be attributed to its antioxidant properties.

\section{Materials and Methods}

\section{Test chemicals}

Sodium arsenite, CAS No. 7784-46-5 (Sigma Chemical Co., USA), Dimethylsulfoxide, (Qualigens, Mumbai, India), Disodium EDTA (Hi Media, Mumbai, India), Ethidium bromide (Sigma Chemical Co.,

*Corresponding author: Anita Mukherjee, Cell Biology and Genetic Toxicology Laboratory, Department of Botany, University of Calcutta.35, Ballygunge Circular Road, Kolkata 700019, India; Tel: +919831061998;E-mail: anitamukherjee28@ gmail.com

Received September 18, 2014; Accepted October 28, 2014; Published November 04, 2014

Citation: Ghosh I, Poddar S, Mukherjee A (2015) Evaluation of the Protective Effect of Hibiscus sabdariffa L. Calyx (Malvaceae) Extract on Arsenic Induced Genotoxicity in Mice and Analysis of its Antioxidant Properties. Biol Med (Aligarh) 7: 218. doi: 10.4172/0974-8369.1000218

Copyright: ( 2015 Ghosh I, et al. This is an open-access article distributed under the terms of the Creative Commons Attribution License, which permits unrestricted use, distribution, and reproduction in any medium, provided the original author and source are credited. 
Citation: Ghosh I, Poddar S, Mukherjee A (2015) Evaluation of the Protective Effect of Hibiscus sabdariffa L. Calyx (Malvaceae) Extract on Arsenic Induced Genotoxicity in Mice and Analysis of its Antioxidant Properties. Biol Med (Aligarh) 7: 218. doi: 10.4172/0974-8369.1000218

Page 2 of 6

USA), Phosphate Buffer Saline (HiMedia, Mumbai, India), Sodium chloride (E. Merck, Mumbai, India) Sodium hydroxide (E. Merck, Mumbai, India), Triton X-100 (Sigma chemical Co., USA), Trizma Base (E. Merck, Mumbai, India), Normal melting point (NMP) and Low melting point (LMP) agarose were purchased from Sigma Chemical Co., St. Louis, MO. While, 2,2-di(4-tert-octylphenyl)-1-picryl-hydrazyl free radical (DPPH, CAS 84077-81-6), phosphoric acid ( $\left.\mathrm{H}_{3} \mathrm{PO}_{4}\right)$ were purchased from Sigma-Aldrich Fine Chemicals, St. Louis, USA.

Ethanol and Aluminium chloride anhydrous (CAS 7446-70-0) were obtained from Merck Specialities (Pvt.) Ltd., India., Gallic acid, ascorbic acid, Folin-Ciocalteu reagent were purchased from SRL, India. Ethanol, ferric chloride $\left(\mathrm{FeCl}_{3}\right)$, sodium carbonate $\left(\mathrm{Na}_{2} \mathrm{CO}_{3}\right)$ were purchased locally and were of analytical grade.

\section{Preparation of plant extract}

Commercially available sachets of dried and crushed Roselle calyxes were obtained from Royal Herbs (Ottoman Group, Egypt). $2 \mathrm{~g}$ of dried and crushed calyxes were contained in each tea bag in each sachet. Extracts were made in hot water before every gavage administration in case of mice while ethanolic extracts were prepared for phytochemical and antioxidant assays. Based on the concentrations of $50,100,150 \mathrm{mg} / \mathrm{kg}$ body weight of mice for Comet assay and 5, 7.5 and $10 \mathrm{mg} / \mathrm{ml}$ solutions for phytochemical and antioxidant assays [6]. The required amounts of crushed, dried calyxes were weighed before every experiment and kept in hot water or ethanol for 5 minutes after which the water or ethanol was filtered to create a bright red extract. Fresh extracts were made before every experiment.

\section{Test animals/organisms}

The studies were conducted on male Swiss albino mice, 8-10 weeks old and weighing 20-25 g. The animals were obtained from the departmental animal house colony, individually ear tagged, and acclimatized for two weeks prior to exposure. Mice were housed in groups of six per cage under standard husbandry and feeding schedules and provided with clean conventional colonies. The animals were housed in polycarbonate cages with a bedding of sterilized rice husk. They were maintained at ambient temperature $\left(25 \pm 2^{\circ} \mathrm{C}\right)$, relative humidity $(60 \pm 5 \%)$ and 12 hour light/dark photoperiod conditions. The animals were fed with standard rodent pellet (M/S 5 Hindustan Lever Foods, Bangalore, India). Throughout the study, mice had access to the feed and water ad libitum. Ethical clearance was obtained from the Institutional Ethics Committee prior to the experimentation (University animal care unit, University of Calcutta, India) [24-29].

\section{Dosage selection}

According to a study of Onyenekwe et al. [29], no deaths were observed in albino mice after fourteen days of administration at doses of $1000-5000 \mathrm{mg} / \mathrm{kg}$ body weight per day, thus the calculated $\mathrm{LD}_{50}$ (Lethal Dose 50) of HES aqueous extract was $>5000 \mathrm{mg} / \mathrm{kg}$ body weight. Based on the above studies, the concentrations of 50,100 and $150 \mathrm{mg}$ of HSE per $\mathrm{kg}$ body weight of mice were taken, respectively. For sodium arsenite a single concentration of $2.5 \mathrm{mg} / \mathrm{kg}$ body weight in distilled water (corresponding 1/10 to the LD50 of the salt /mice) was chosen based on the study reported by Adetutu et al. [30].

\section{Experimental Design}

The animals were divided into seven experimental groups with 6 male mice in each group. The volume of test compound was $10 \mathrm{~mL} / \mathrm{kg}$ body weight for each dose.
Group 1: Negative controls received distilled water in drinking water.

Group 2: Animals were gavaged with HSE-50 mg/kg body weight for seven days.

Group 3: Animals received a single interperitoneal (i.p.) injection of sodium arsenite $(2.5 \mathrm{mg} / \mathrm{kg}$ body weight), 24hours before the day of sacrifice.

Group 4: Animals were administered with HSE-50 $\mathrm{mg} / \mathrm{kg}$ body weight for seven days and on day 7 received a single acute dose of sodium arsenite ( $2.5 \mathrm{mg} / \mathrm{kg}$ body weight; i.p.).

Group 5: Animals were gavaged with HSE $100 \mathrm{mg} / \mathrm{kg}$ body weight for 7 consecutive days

Group 6: Animals were primed with HSE (100 mg/kg body weight) for 7 consecutive days and on the seventh day of experiment received a single acute dose of sodium arsenite $(2.5 \mathrm{mg} / \mathrm{kg}$ body weight; i.p.).

Group 7: Animals were gavaged with HSE $150 \mathrm{mg} / \mathrm{kg}$ body weight for 7 consecutive days.

Group 8: Animals were primed with HSE ( $150 \mathrm{mg} / \mathrm{kg}$ body weight) for 7 consecutive days and on the seventh day of experiment received a single acute dose of sodium arsenite ( $2.5 \mathrm{mg} / \mathrm{kg}$ body weight; i.p.).

Animals were sacrificed by cervical dislocation 24 hours after the last treatment. After sacrificing them, the femurs were flushed in phosphate buffer solution to obtain suspensions of bone marrow cells.

\section{Alkaline single cell gel electrophoresis or Comet assay}

The alkaline single cell gel electrophoresis/Comet assay was performed by the method of Singh et al. [31] with slight modifications and following the guidelines of Tice et al. [32]. Single cell suspensions of the bone marrow cells were obtained by flushing the femurs with ( 1 $\mathrm{ml}$ ) PBS [33]. In the control and treated animals viable bone marrow cells were obtained by checking cell viability as measured by Trypan blue dye exclusion method [34]. All samples examined exceeded $90 \%$ viability after scanning several fields. Slides were prepared by mixing the bone marrow cell suspension with $1 \%$ low melting point agarose (prepared in $\mathrm{Ca}^{2+}, \mathrm{Mg}^{2+}$ free PBS); layered on the slide base coated with $1 \%$ normal melting point agarose and cover slips were immediately placed over the second layer.

Slides were then placed on ice packs for $5 \mathrm{~min}$. to solidify the agarose after which the cover slips were removed and the third layer of $0.5 \%$ low melting point agarose was placed and solidified again on ice. The slides were then immersed in chilled lysing solution $(2.5 \mathrm{M} \mathrm{NaCl}$, $100 \mathrm{mM}$ EDTA, $10 \mathrm{mM}$ Trizma, $10 \%$ DMSO and $1 \%$ Triton X-100, $\mathrm{pH} 10.0)$ at $4^{\circ} \mathrm{C}$, overnight. Then the slides were subjected to DNA unwinding in chilled alkaline electrophoresis buffer solution $(300 \mathrm{mM}$ $\mathrm{NaOH}$ and $1 \mathrm{mM} \mathrm{Na2EDTA}, \mathrm{pH}>13$ ) for $20 \mathrm{~min}$ and subsequently electrophoresis was performed at $0.7 \mathrm{~V} / \mathrm{cm}$ and $300 \mathrm{~mA}$ at $4^{\circ} \mathrm{C}$ for 30 $\min$.

After electrophoresis the slides were neutralized with Tris buffer ( $400 \mathrm{mM}$, pH 7.4). Slides were stained with $20 \mu \mathrm{g} / \mathrm{ml}$ ethidium bromide (EtBr) and stored at $4^{\circ} \mathrm{C}$ in a humidified slide box until scoring. Slides were scored at a final magnification of $400 \times$ using an image analysis system (Komet 5.5, Kinetic Imaging, Andor technology, Nottingham, UK) attached to a fluorescence microscope (Leica, Germany) equipped with an attachment of a CCD camera. The comet parameters used to measure DNA damage in the cells were tail DNA (\%) [35]. 
Citation: Ghosh I, Poddar S, Mukherjee A (2015) Evaluation of the Protective Effect of Hibiscus sabdariffa L. Calyx (Malvaceae) Extract on Arsenic Induced Genotoxicity in Mice and Analysis of its Antioxidant Properties. Biol Med (Aligarh) 7: 218. doi: 10.4172/0974-8369.1000218

\section{Statistical Analysis}

For all statistical analyses, the level of significance was established at $\mathrm{P}<0.05$. Data were analyzed using the statistical functions of Sigma Stats 3.0 (SPSS Inc., Chicago, IL). A one-way ANOVA followed by Duncan's multiple range test (DMRT) was carried out to detect significant differences in \% Tail DNA, if any, amongst different treatment sets.

\section{Determination of total polyphenol content}

The total polyphenol content of the extract was determined according to the method of McDonald et al. and Roy et al. [36,37] with slight modifications. Briefly, $0.5 \mathrm{ml}$ of extract $(5,7.5,10 \mathrm{mg} / \mathrm{ml})$ was mixed with Folin-Ciocalteu reagent $(5 \mathrm{ml}, 1: 10$ dilution with distilled water) and further neutralized by aqueous $\mathrm{Na}_{2} \mathrm{CO}_{3}(4 \mathrm{ml}, 1 \mathrm{M})$ solution. The reaction mixture was then allowed to stand for $15 \mathrm{~min}$. at room temperature. The absorbance of the reaction mixture was measured at $765 \mathrm{~nm}$ using a UV-visible spectrophotometer. The calibration curve was prepared using solutions of gallic acid (standard) in ethanol with final concentrations in reaction mix ranging from $0-35 \mu \mathrm{g} / \mathrm{ml}$. The total polyphenol content was expressed in terms of milligram of gallic acid equivalent per gram of extract (mg GAE/g). Three replicates were performed for each concentration of HSE. Results are represented as mean \pm standard deviation.

\section{Determination of total flavonoids}

The method of Ordonez et al. [38] and Taie et al. [,39] was followed for the estimation of total flavonoid content with minor modifications. Briefly, $0.5 \mathrm{ml}$ of $2 \% \mathrm{AlCl} 3$ in ethanol solution was added to $0.5 \mathrm{ml}$ of the extract $(5,7.5,10 \mathrm{mg} / \mathrm{ml})$. The reaction mixture was then allowed to stand for $1 \mathrm{~h}$ at room temperature. The absorbance was measured at 420 nm using a UV-visible spectrophotometer against the sample blank. Total flavonoid content 8 was calculated as quercetin equivalent $(\mathrm{mg} / \mathrm{g})$ obtained from calibration curve $(0-33 \mu \mathrm{g} / \mathrm{ml})$. The total flavonoid content was expressed in terms of milligram of quercetin equivalent per gram of extract (mg QUE/g). Three replicates were performed for each concentration. Results are represented as mean \pm S.D.

\section{Scavenging effect on 2, 2-di (4-tert-octylphenyl)-1- picrylhydrazyl free radical}

The DPPH radical scavenging capacity was determined using the method described by earlier researchers [40,41]. $10 \mu \mathrm{l}$ ethanolic extracts of HSE (at concentration of $0.1,0.25,0.5,2.5,5,7.5$ and 10 $\mathrm{mg} / \mathrm{ml}$ ) were mixed with $3 \mathrm{ml}$ of $6 \times 10-5 \mathrm{M} \mathrm{DPPH}$ in ethanol. After 30 min of incubation in the dark at room temperature, the absorbance at $517 \mathrm{~nm}$ was measured against blank. Three replicas were made for each concentration.

The inhibition percentage of DPPH radical was calculated according to the formula:

$\mathrm{DPPH}$ radical scavenging capacity $\%=[(\mathrm{ADPPH}-\mathrm{AEXTR}) /$ $\mathrm{ADPPH}] \times 100$.

Where:

ADPPH is the absorbance of the control solution (containing only DPPH).

AEXTR is the absorbance in the presence of antioxidant.

Ascorbic acid was used as a positive control.

\section{Assay of Ferric Reducing Antioxidant Power (FRAP)}

The FRAP assay was performed according to the method of Benzie and Strain [42] with slight modifications. The FRAP reagent included 10 parts of $300 \mathrm{mM}$ sodium acetate buffer ( $\mathrm{pH} 3.6$ ), 1 part of $10 \mathrm{mM}$ TPTZ (2, 4, 6-tripyridyl-s-triazine) solution in $40 \mathrm{mM} \mathrm{HCl}$ and 1 part of $20 \mathrm{mM} \mathrm{FeCl}_{3} \cdot 6 \mathrm{H}_{2} \mathrm{O}$ solution. The fresh working solution was prepared by mixing $20 \mathrm{~mL}$ acetate buffer, $2 \mathrm{~mL}$ TPTZ solution and 2 $\mathrm{mL} \mathrm{FeCl} .6 \mathrm{H}_{2} \mathrm{O}$ solution and then warmed at $37^{\circ} \mathrm{C}$ before using. $67 \mu \mathrm{L}$ of HSE from each concentration $(2.5,5,7.5$ and $10 \mathrm{mg} / \mathrm{ml})$ were allowed to react with $1 \mathrm{~mL}$ of the FRAP Reagent for 10 minutes on a warm water bath. Readings of the colored product [ferrous tripyridyltriazine complex] were then taken at $593 \mathrm{~nm}$. The standard curve of ascorbic acid was referred to. Results are expressed in milligram of ascorbic acid equivalent per gram of extract (mgAAE/g) (Table 1).

\section{Results}

\section{Total polyphenol and flavonoid content}

The total polyphenol content of $H$. sabdariffa calyx extracts was 2.20 $\pm 0.08 \mathrm{mg}$ gallic acid equivalent/g of extract $(\mathrm{GAE} / \mathrm{g})$, as determined with reference to the standard curve of gallic acid ( $y=0.088 x+0.132$, $\mathrm{R} 2=0.99$ ). Total flavonoid content of $H$. sabdariffa calyx extracts was $3.20 \pm 0.11 \mathrm{mg}$ quercetin equivalent/g of the extract (QUE/g) as determined with reference to the standard curve of Quercetin $(y=0.037 x+0.0017, R 2=0.99)$ (Table 2).

Scavenging effect on 2, 2-di(4-tert-octylphenyl)-1-picrylhydrazyl (DPPH) free radical. The DPPH radical scavenging activity of H. sabdariffa calyx extracts (HSE) at various doses was assessed spectrophotometrically by the quantitative estimation of the discoloration of the same. HSE at various concentrations $(0.1,0.25$, $0.5,2.5,5,7.5$ and $10 \mathrm{mg} / \mathrm{mL}$ ) showed increasing inhibition of DPPH with increase in concentration. The value was significant $(p<0.05)$ at the concentrations tested. The DPPH radical scavenging activity of HSE ranged between 14.09 to $35.92 \%$ from 0.1 to $10 \mathrm{mg} / \mathrm{mL}$ solutions of HSE respectively (Table 2); whereas in ascorbic acid $(4 \mu \mathrm{g} / \mathrm{mL})$ it showed $71.48 \pm 1.85 \%$ scavenging activity.

\section{Assay of Ferric Reducing Antioxidant Power (FRAP)}

The antioxidant capacity of $H$. sabdariffa L. calyx extract was estimated from its ability to reduce TPTZ-Fe (III) complex to a TPTZ$\mathrm{Fe}$ (II) complex. The FRAP value of $H$. sabdariffa L. calyx extract was expressed terms of $\mathrm{mg}$ ascorbic acid equivalent (AAE) per gram of the extract and the value was determined as $0.784 \pm 0.01 \mathrm{mgAAE} / \mathrm{g}$. The FRAP values increased with increasing concentrations of HSE (Table 2) [43].

\section{Discussion}

Roselle (H. sabdariffa) is known as a delicacy as well as for its medicinal properties. It is an excellent source of dietary phytochemicals such as anthocyanins, polyphenols and flavonoids. The use of Roselle petals, calyx and fruits as natural antioxidants, natural colorants, and an ingredient of functional foods has sprouted interest for the research of its antioxidant and antigenotoxic properties.

The purpose of the present study was to determine whether and to what extent HSE can modulate the genotoxic damage induced by sodium arsenite. HSE is a rich source of antioxidant that can scavenge free radicals [44] and it is known that the mechanism of the Asinduced genotoxicity is ROS mediated [45]. Therefore looking for a 
Citation: Ghosh I, Poddar S, Mukherjee A (2015) Evaluation of the Protective Effect of Hibiscus sabdariffa L. Calyx (Malvaceae) Extract on Arsenic Induced Genotoxicity in Mice and Analysis of its Antioxidant Properties. Biol Med (Aligarh) 7: 218. doi: 10.4172/0974-8369.1000218

Page 4 of 6

\begin{tabular}{|c|c|c|c|c|c|c|c|}
\hline \multirow[b]{2}{*}{ Group } & \multirow[b]{2}{*}{$\begin{array}{l}\text { Treatment } \\
\text { (days) }\end{array}$} & \multirow[b]{2}{*}{ Compound } & \multirow[b]{2}{*}{ Dose(mg/kg.b.wt) } & \multicolumn{4}{|c|}{ Tail DNA (\%) } \\
\hline & & & & Mean & $\pm \mathrm{SD}$ & $\begin{array}{c}\text { Observed } \\
\text { Increase (over control) }\end{array}$ & $\begin{array}{l}\text { Sum of individual } \\
\text { increase of the two } \\
\text { compounds }\end{array}$ \\
\hline 1 & 7 & Water & $10 \mathrm{ml}$ & 1.99 & $\pm 1.43 a^{*}$ & - & - \\
\hline 2 & 7 & HSE & 50 & 3.71 & $\pm 2.05 a, d$ & 1.72 & - \\
\hline 3 & 1 & As & 2.5 & 26.65 & $\pm 10.46 \mathrm{~b}$ & 24.66 & - \\
\hline 4 & $7+1$ & $\mathrm{HSE}+\mathrm{As}$ & $50+2.5$ & 4.78 & $\pm 3.59 c$ & 2.79 & $<26.38^{\star *}$ \\
\hline 5 & 7 & HSE & 100 & 7.63 & $\pm 1.23 \mathrm{~d}$ & 5.64 & - \\
\hline 6 & $7+1$ & $\mathrm{HSE}+\mathrm{As}$ & $100+2.5$ & 9.48 & $\pm 2.49 \mathrm{e}$ & 7.49 & $<30.3^{\star *}$ \\
\hline 7 & 7 & HSE & 150 & 8.72 & $\pm 2.67 d$ & 6.73 & - \\
\hline 8 & $7+1$ & $\mathrm{HSE}+\mathrm{As}$ & $150+2.5$ & 15.48 & $\pm 1.59 f$ & 13.49 & $<31.39^{\star *}$ \\
\hline
\end{tabular}

*Values in a vertical column followed by the same letter $(a, a)$ or $(b, b)$ or $(d, d)$ are not significantly different at $5 \%$ level ,whereas values with different letters $(a, b)$ or $(b, c)$ are significant at the $5 \%$ level as determined by Duncan's multiple range test; Each value is the average of the median values of 6 animals;

** significantly less at $5 \%$ level,

Table 1: Effect of aqueous extract of Hibiscus sabdariffa L. calyx extracts (HSE) on Arsenic (As) induced DNA damage (\% Tail DNA) in mice bone marrow cells

\begin{tabular}{|c|c|c|c|c|}
\hline $\begin{array}{l}\text { Total Polyphenol (mgGAE/g of extract) } \\
\text { [mean } \pm \text { SD] }]^{*}\end{array}$ & $\begin{array}{l}\text { Total flavonoid (mgQUE/g of extract) } \\
\text { [mean } \pm \text { SD] }]^{*}\end{array}$ & $\begin{array}{l}\mathrm{FRAP}(\mathrm{mg} \mathrm{AAE} / \mathrm{g} \text { of extract }) \\
{[\text { mean } \pm \mathrm{SD}]^{*}}\end{array}$ & $\%$ DPPH & $\begin{array}{l}\text { radical Scavenging Activity } \\
\text { of } 100 \% \mathrm{HSE}\end{array}$ \\
\hline $2.20 \pm 0.08$ & $3.20 \pm 0.11$ & $0.784 \pm 0.01$ & & $35.92 \% \pm 0.8$ \\
\hline
\end{tabular}

*mean of three replicates; SD- standard deviation

Table 2: Total polyphenol, flavonoid content and antioxidant activities of Hibiscus sabdariffa L. calyx extract

suitable dietary supplement is important in the management of Asinduced toxicity.

Previous studies indicated that ROS radicals play pivotal role in the genotoxicity of arsenical compounds in mammalian cells $[17,45,46]$. Literature survey revealed that in majority of reports, antioxidant prophylactic were successful in ameliorating genotoxicity of arsenic [4649]. This study was aimed to study the protection that could be afforded by priming mice for 7 consecutive days with HSE before challenge with sodium arsenite. Administration of HSE (at 50,100 and $150 \mathrm{mg}$ $/ \mathrm{kg}$ body weight) reduced significantly the DNA damage induced by sodium arsenite in a dose dependent manner. This antigenotoxic property of HSE can be attributed to its antioxidant property of the phytochemical constituents of the plant. The dried flower extracts of $H$. sabdariffa was reported to inhibit significantly the unscheduled DNA synthesis (UDS) induced by tert-butyl hydroquinone [46]. Comet assay can measure DNA damage directly whereas UDS is an indirect method of determination of the extent of DNA damage through the DNA repair synthesis $[40,50]$. Hence, Comet assay is a more advantageous method over the UDS method for assessing DNA damage.

Free radical scavenging and antigenotoxic activities of natural phenolic compounds in dried flowers of $H$. sabdariffa are reported in the literature [51]. Roselle flower organic extract showed antioxidant capacity that seems to be a consequence of the polyphenol content and other antioxidants such as ascorbic acid, eugenol, and limonene [52]. The earlier reports demonstrated that the phenolic compounds of the ethanolic or water extracts of dried flowers of $H$. sabdariffa can scavenge oxygen free radicals and nitrogen oxide radicals and could prevent sodium arsenite-induced in vivo bone marrow micronucleus induction in rats [53] and in mice [30].

In the present study, the inhibitory effects of HSE further underscore that active oxygen species are involved in its (Arsenic) genotoxicity. HSE contains $141.09 \mathrm{mg} / 100 \mathrm{~g}$ of ascorbic acid, 1.88 $\mathrm{mg} / 100 \mathrm{~g}$ of beta-carotene, $296 \mathrm{mg} / 100 \mathrm{~g}$ of total phenolic compounds as gallic acid equivalent and $2.53 \mathrm{mg} / 100 \mathrm{~g}$ of anthocyanin expressed as delphinidin-3-glucosiode [54]. The presence of polyphenols was detected as $220 \mathrm{mg} / 100 \mathrm{~g}$ GAE in the present study. The FRAP assay is based on the reducing ability of antioxidant compounds present in the sample which showed substantial reducing ability of HSE as a result of its antioxidant property. The DPPH radical scavenging activity was also of a considerable amount. Therefore, it can be asserted that $H$. sabdariffa possesses considerable antioxidant properties based on the results of the FRAP assay and DPPH assays and also contains a substantial amount of flavonoids and polyphenols, which can contribute to its antigenotoxic properties. Our results are in line with the previous findings. Hibiscus anthocyanins also showed protective effect against hepatic toxicity which added additional support to our present findings [4].

Therefore, the crude aqueous extract of $H$. sabdariffa calyxes could be used as a dietary supplement to prevent the clastogenic effects of arsenic exposure through drinking water. This would benefit people exposed in As-affected areas and in the cost-effective management of the problem. Since the data reported in this study were generated from short-term treatment, it is recommended that long-term animal studies should be conducted to evaluate the effects of these extracts on biomarkers of oxidative stress such as DNA damage.

\section{Conclusion}

Hibiscus sabdariffa L. calyx extract harbours antigenotoxic properties that can be attributed to its antioxidant properties and free radical scavenging activities. Hence, it can be used to combat Arsenic induced genotoxicity.

\section{References}

1. Perry LM (1980) Medicinal plants of East and South East Asia. MIT Press, Cambridge, London, UK.

2. Tee PL, Yusof S, Mohamed S, Umar NA, Mustapha NM (2002) Effect of Roselle (Hibiscus sabdariffa L.) on serum lipids of Sprague Dawley rats. Nutrition and Food Science 32: 190-196.

3. Dalziel TM (1973) The useful plants of West Tropical Africa. 3rd Edition, Watmought Ltd., Bradford, London, 526-530.

4. Wang SY, Jiao H (2000) Scavenging capacity of berry crops on superoxide radicals, hydrogen peroxide, hydroxyl radicals, and singlet oxygen. J Agric Food Chem 48: 5677-5684. 
Citation: Ghosh I, Poddar S, Mukherjee A (2015) Evaluation of the Protective Effect of Hibiscus sabdariffa L. Calyx (Malvaceae) Extract on Arsenic Induced Genotoxicity in Mice and Analysis of its Antioxidant Properties. Biol Med (Aligarh) 7: 218. doi: 10.4172/0974-8369.1000218

Page 5 of 6

5. Ross IA (2003) Hibiscus sabdariffa. In Medicinal Plants of the World. Vol 1, 2nd Edition, Humana Press: New Jersey, 267-27515.

6. Azqueta A, Slyskova J, Langie SA, O'Neill Gaivão I, Collins A (2014) Comet assay to measure DNA repair: approach and applications. Front Genet 5: 288

7. Wang CJ, Wang JM, Lin WL, Chu CY, Chou FP, et al. (2000) Protective effect of Hibiscus anthocyanins against tert-butyl hydroperoxide-induced hepatic toxicity in rats. Food Chem Toxicol 38: 411-416.

8. Hirunpanich V, Utaipat A, Morales NP, Bunyapraphatsara N, Sato H, et al (2005) Antioxidant effects of aqueous extracts from dried calyx of Hibiscus sabdariffa Linn. (Roselle) in vitro using rat low-density lipoprotein (LDL). Biol Pharm Bull 28: 481-484.

9. Lin $\mathrm{HH}$, Chen JH, Kuo WH, Wang CJ (2007) Chemopreventive properties of Hibiscus sabdariffa L. on human gastric carcinoma cells through apoptosis induction and JNK/p38 MAPK signaling activation. Chem Biol Interact 165: 59-75.

10. Tom V, Rodolfo JH, James ES, Qing-Li W (2013) ACS Symposium Series 1127 (14): 209-230.

11. Hertog MG, Feskens EJ, Hollman PC, Katan MB, Kromhout D (1993) Dietary antioxidant flavonoids and risk of coronary heart disease: the Zutphen Elderly Study. Lancet 342: 1007-1011.

12. Haruna AK (1997) Cathartic activity of Soborodo: the aqueous extract of calyx of Hibiscus sabdariffa L. Phytother. Res 11: 307-308.

13. Chewonarin $\mathrm{T}$, Kinouchi $\mathrm{T}$, Kataoka K, Arimochi H, Kuwahara T, Vinitketkumnuen U, Ohnishi Y (1999) Effects of roselle (Hibiscus sabdariffa Linn.), a Thai medicinal plant, on the mutagenicity of various known mutagens in Salmonella typhimurium and on formation of aberrant crypt foci induced by the colon carcinogens azoxymethane and 2-amino-1-methyl-6-phenylimidazo[4,5-b] pyridine in $\mathrm{F} 344$ rats. Food Chem Toxicol 37: 591-601.

14. Tseng TH, Hsu JD, Lo MH, Chu CY, Chou FP, et al. (1998) Inhibitory effect of Hibiscus protocatechuic acid on tumor promotion in mouse skin. Cancer Lett 126: 199-207.

15. Azqueta A, Slyskova J, Langie SA, O'Neill Gaivão I, Collins A (2014) Come assay to measure DNA repair: approach and applications. Front Genet 5: 288.

16. Akter KF, Owens G, Davey DE, Naidu R (2005) Arsenic speciation and toxicity in biological systems. Rev Environ Contam Toxicol 184: 97-149.

17. Hei TK, Liu SX, Waldren C (1998) Mutagenicity of arsenic in mammalian cells: role of reactive oxygen species. Proc Natl Acad Sci U S A 95: 8103-8107.

18. Mandal BK, Chowdhury TR, Samanta G, Basu GK, Chowdhury PP, et al (1996) Arsenic in ground water in seven districts of West Bengal, India-the biggest arsenic calamity in the world. Curr Sci 70: 976.

19. World Health Organization (1981) Arsenic: Environmental Health Criteria18 International Program on Chemical Safety, Geneva.

20. United States Environmental Protection Agency (2001) Ground Water and Drinking Water. Arsenic in drinking water.

21. Qureshi S, Al-Harbi MM, Ahmed MM, Raza M, Giangreco AB, et al. (1993) Evaluation of genotoxic, cytotoxic and antitumor properties of Commiphora molmol using normal and Ehrlish ascites carcinoma cell-bearing Swiss albino mice. Cancer Chemotherapy Pharmacol 33: 130-138

22. Edenharder R, Frangart J, Hager M, Hofmann P, Rauscher R (1998) Protective effects of fruits and vegetables against in vivo clastogenicity of cyclosphosphamide or benzo[a]pyrene in mice. Food Chem Toxicol 36: 637-645.

23. Mukhopadhyay MJ, Mukherjee A (2000) Clastogenic effect of ginger rhizome in mice. Phytother Res 14: 555-557.

24. Mukhopadhyay MJ, Mukherjee A (1998) Inhibition of clastogenic effect of cyclophosphamide and mytomycin C by neem leaf-extracts. Phytotherapy Research 12: 409- 412

25. Mukhopadhyay MJ, Saha A, Dutta A, De B, Mukherjee A (1998) Genotoxicity of sennosides on the bone marrow cells of mice. Food Chem Toxicol 36: 937-940.

26. Mukhopadhyay MJ, Saha A, Mukherjee A (1998) Studies on the anticlastogenic effect of turmeric and curcumin on cyclophosphamide and mitomycin $C$ in vivo. Food Chem Toxicol 36: 73-76.

27. Ostling O, Johanson KJ (1984) Microelectrophoretic study of radiation-induced DNA damages in individual mammalian cells. Biochem Biophys Res Commun 123: 291-298.
28. Kumaravel TS, Jha AN (2006) Reliable Comet assay measurements for detecting DNA damage induced by ionising radiation and chemicals. Mutat Res 605: 7-16.

29. Onyenekwe PC, Ajani EO, Ameh DA, Gamaniel KS (1999) Antihypertensive effect of roselle (Hibiscus sabdariffa) calyx infusion in spontaneously hypertensive rats and a comparison of its toxicity with that in Wistar rats. Cel Biochem Funct 17: 199-206.

30. Adetutu A, Odunola OA, Owoade OA, Adeleke OA, Amuda OS (2004) Anticlastogenic effects of Hibiscus sabdariffa fruits against sodium arseniteinduced micronuclei formation in erythrocytes in mouse bone marrow. Phytother Res 18: 862-864.

31. Singh NP, McCoy MT, Tice RR, Schneider EL (1988) A simple technique for quantitation of low levels of DNA damage in individual cells. Exp Cell Res 175 $184-191$

32. Tice RR, Agurel E, Anderson D, Burlinson B, Hartmann A, et al. (2000) Single cell gel/comet assay: guidelines for in vitro and in vivo genetic toxicology testing. Environ Mol Mutagen 35: 206-21.

33. Sasaki YF, Kawaguchi S, Kamaya A, Ohshita M, Kabasawa K, (2002) The comet assay with 8 mouse organs: results with 39 currently used food additives. Mutat Res 519: 103-119.

34. Hudson L, Hay FC (1980) Practical Immunology. Blackwell Scientific Publications, Oxford, 29-31.

35. Jothiramajayam M, Sinha S, Ghosh M, Mukherjee A (2013) Evaluation of multiendpoint assay to detect genotoxicity and oxidative stress in mice exposed to sodium fluoride. Mutat Res 751: 59-65.

36. McDonald S, Prenzler PD, Antolovich M, Robards K (2001) Phenolic content and antioxidant activity of olive extracts. Food Chem 73: 73-84.

37. Roy N, Mondal S, Laskar RA, Basu S, Mandal D, et al. (2010) Biogenic synthesis of $\mathrm{Au}$ and $\mathrm{Ag}$ nanoparticles by Indian propolis and its constituents. Colloids Surf B Biointerfaces 76: 317-325

38. Ordonez A, Gomez J, Vattuone M (2006) Antioxidant activities of Sechium edule (Jacq.) Swartz extracts. Food Chem 97: 452458

39. Taie HAA, Salama ZA-ER, Radwan S (2010) Potential activity of basil plants as a source of antioxidants and anticancer agents as affected by organic and bio-organic fertilization. Not Bot Hort Agrobot Cluj 38: 119-127.

40. Liu H, Qiu N, Ding H, Yao R (2008) Polyphenols contents and antioxidant capacity of 68 Chinese herbals suitable for medical or food uses. Food Res Int 41: 363-370.

41. Lu M, Yuan B, Zeng M, Chen J (2011) Antioxidant capacity and major phenolic compounds of spices commonly consumed in China. Food Res Int 44: 530 536.19

42. Benzie IF, Strain JJ (1996) The ferric reducing ability of plasma (FRAP) as a measure of "antioxidant power": the FRAP assay. Anal Biochem 239: 70-76.

43. Heddle JA (1974) Combinations of mutagens: distinguishing possible outcomes. Mutat Res 24: 77-79.

44. Tseng TH, Kao ES, Chu CY, Chou FP, Lin Wu HW, et al. (1997) Protective effects of dried flower extracts of Hibiscus sabdariffa L. against oxidative stress in rat primary hepatocytes. Food Chem Toxicol 35: 1159-1164.

45. Liu SX, Athar M, Lippai I, Waldren C, Hei TK (2001) Induction of oxyradicals by arsenic: implication for mechanism of genotoxicity. Proc Natl Acad Sci U S A 98: 1643-1648.

46. Sinha S, Saxena R, Singh S (2005) Chromium induced lipid peroxidation in the plants of Pistia stratiotes L.: role of antioxidants and antioxidant enzymes. Chemosphere 58: 595-604.

47. Biswas S, Talukder G, Sharma A (1999) Protection against cytotoxic effects of arsenic by dietary supplementation with crude extract of Emblica officinalis fruit. Phytother Res 13: 513-516.

48. Das T, Roychoudhury A, Sharma A, Talukder G (1993) Modification of clastogenicity of three known clastogens by garlic extract in mice in vivo. Environ Mol Mutagen 21: 383-388.

49. Patra M, Bhowmik N, Bandopadhyay B, Sharma A (2004) Comparison of mercury, lead and arsenic with respect to genotoxic effects on plant systems and the development of genetic tolerance. Environ Exp Bot 52: 199-223. 
Citation: Ghosh I, Poddar S, Mukherjee A (2015) Evaluation of the Protective Effect of Hibiscus sabdariffa L. Calyx (Malvaceae) Extract on Arsenic Induced Genotoxicity in Mice and Analysis of its Antioxidant Properties. Biol Med (Aligarh) 7: 218. doi: 10.4172/0974-8369.1000218

50. Hsia MTS, Kreamer BL and Dolara P (1983) A rapid and simple method to quantitate chemically induced unscheduled DNA synthesis in freshly isolated rat hepatocytes facilitated by DNA retention of membrane filters. Mutation Research 122: 177-185.

51. Prenesti E, Berto S, Daniele PG, Toso S (2007) Antioxidant power quantification and cold infusions of Hibiscus sabdariffa flowers. Food Chem 100: 433-438.

52. Chen CC, Hsu JD, Wang SF, Chiang HC, Yang MY, et al. (2003) Hibiscus sabdariffa extract inhibits the development of atherosclerosis in cholesterol-fed rabbits. J Agric Food Chem 51: 5472-5477.

53. Farombi EO, Fakoya A (2005) Free radical scavenging and antigenotoxic activities of natural phenolic compounds in dried flowers of Hibiscus sabdariffa L. Mol Nutr Food Res 49: 1120-1128.

54. Wong PK, Yusof S, Ghazali HM, Che Man YB (2002) Physicochemical characteristics of Roselle (Hibiscus sabdariffa L.) Nutr Food Sci 32: 68-73. 